\title{
Indigenous Australians, Intellectual Disability and Incarceration: A Confluence of Rights Violations
}

\author{
Claire E. Brolan ${ }^{1,2,3, *}$ and David Harley ${ }^{2, *}$ \\ 1 Dalla Lana School of Public Health, The University of Toronto, Toronto, ON M5T 3M7, Canada \\ 2 Queensland Centre for Intellectual and Developmental Disability, \\ Mater Research Institute-University of Queensland, Brisbane, QLD 4101, Australia \\ 3 Melbourne School of Population and Global Health, University of Melbourne, \\ Melbourne, VIC 3010, Australia \\ * Correspondence: c.brolan@uq.edu.au (C.E.B.); d.harley@uq.edu.au (D.H.); Tel: +61-7-3163-2412 (D.H.)
}

Received: 4 September 2017; Accepted: 30 January 2018; Published: 12 February 2018

\begin{abstract}
This article reviews the health and wellbeing of Aboriginal and Torres Strait Islander Australians with intellectual disability in the Australian prison system through a human rights lens. There is an information gap on this group of Australian prisoners in the health and disability literature and the multi-disciplinary criminal law and human rights law literature. This article will consider the context of Indigenous imprisonment in Australia and examine the status of prisoner health in that country, as well as the status of the health and wellbeing of prisoners with intellectual disability. It will then specifically explore the health, wellbeing and impact of imprisonment on Indigenous Australians with intellectual disability, and highlight how intersectional rights deficits (including health and human rights deficits) causally impact the ability of Indigenous Australians with intellectual disability to access due process, equal recognition and justice in the criminal justice and prison system. A central barrier to improving intersectional and discriminatory landscapes relating to health, human rights and justice for Indigenous Australian inmates with intellectual disability, and prisoners with intellectual disability more broadly in the Australian context, is the lack of sufficient governance and accountability mechanisms (including Indigenous-led mechanisms) to enforce the operationalisation of consistent, transparent, culturally responsive, rights-based remedies.
\end{abstract}

Keywords: Aboriginal and Torres Strait Islander; Indigenous Australians; persons with intellectual disability; prisoners with intellectual disability; human right to health; human rights

\section{Introduction}

The purpose of this article is to review the health and wellbeing of Aboriginal and Torres Strait Islander Australians with intellectual disability in the Australian prison system through a human rights lens, and to highlight how intersectional rights deficits (including health and human rights deficits) can detrimentally and unlawfully impact the ability of Indigenous Australians in such environments to equal recognition before the law and just, accountable, transparent and culturally responsive processes and outcomes. A broad approach to the definition of intellectual disability is taken, and we recognise overlap in individuals and in the legal system response with and to cognitive and psychiatric impairment. Psychiatric illness is common in persons with intellectual disability, while cognition may be impaired permanently or for prolonged periods by pathological processes (for example, cerebrovascular accident, or central nervous system changes associated with Fragile- $X$ syndrome or fetal alcohol spectrum disorder) or for shorter periods because of depression, intoxication with alcohol or other substances, and through other causes. Pursuant the social model of disability that underscores the vision and content of the Convention on the Rights of Persons with Disabilities (CRPD), disability is the result of the interaction between people living with impairments and barriers in the physical, 
attitudinal, communication and social environment, while impairment is a medical condition that leads to disability.

Focus on definitions and constitutive factors of disability 'type' can err academic discourse toward the medical model of disability. It is suggested such focus detracts and removes attention from the needs, voice, wishes and experiences of the person with intellectual disability or cognitive or psychiatric impairment, and rights-based responses to physical, attitudinal, communication, social and cultural barriers and inequalities for that person. From the outset, it is suggested the multi-layered cultural, social and environmental barriers, inequalities, power differentials, rights violations and injustices should be at the fore of a constructive, rights-based academic examination into First Nations and disability, rather than focus on disability definition and type.

It follows there is a limited but important burgeoning literature on Indigenous Australians and intellectual disability, which is complemented by recently released Federal data on the prevalence of disability among the heterogeneous Indigenous Australian populace (see Box 1) (Roy and Balaratnasingam 2014; Australian Bureau of Statistics 2017a). This article highlights the gaps between the foregoing by discussing the health and wellbeing of Indigenous Australians with intellectual disability in remand and custody (Shepherd et al. 2017). The information gap on this group of Australian prisoners is found in the health and disability literature and the multi-disciplinary criminal law and human rights law literature.

Because of the interdisciplinary and cross-cutting nature of the issues reviewed and presented in this article, it is important to trace the surrounding contextual landscape and its complexity. Therefore, this paper will be divided into four sections that will examine distinct but inter-related topics. In the Background section, we will begin by setting out an overview of Indigenous imprisonment in Australia. Next, we will briefly examine prisoner health in Australia, then more deeply explore what is known about the prevalence, health and wellbeing of persons with intellectual disability in the Australian prison system. In the third section, we will narrow our investigation to focus on the health, wellbeing and impact of imprisonment on Indigenous Australians with intellectual disability, and in the fourth and final section provide suggestions for policy, planning, advocacy, and research. Suggestions in the final section are grounded in three significant human rights instruments: the United Nations (UN) Declaration on the Rights of Indigenous Peoples (United Nations General Assembly 2007); United Nations (2006); and International Covenant on Economic Social and Cultural Rights (United Nations General Assembly 1966). The key right to health provisions in these documents, which underpin the final section, are set out in Box 2 (United Nations General Assembly 2007; United Nations 2006; United Nations General Assembly 1966).

Before proceeding it is important to note the authors of this paper are non-Indigenous Australians. Therefore, this paper cannot and does not present or represent the diversity of the voices or the views of Aboriginal or Torres Strait Islander persons, nor has it been researched or written from the space of the lived experience of Australia's Indigenous peoples. We acknowledge that respect, recognition, ownership and leadership, and identity, are of acute significance to the First Nations peoples of Australia, including in the cross-cutting areas of public health research, health and disability, and criminal justice; areas that separately and together are infused with Western and neo-liberal cultural perspectives, power, histories of discrimination and oppression, and bias. Therefore, in developing this paper, we are mindful of the deep spiritual and holistic values and belief systems many Indigenous Australians have toward their family's, community's and people's health and wellbeing (National Aboriginal Health Strategy Working Party 1989; National Aboriginal and Torres Strait Islander Health Council for the Australian Health Ministers' Conference NATSIHC; Rountree and Smith 2016; Kite and Davy 2015; Shahid et al. 2009; McGrath and Phillips 2008), the diverse Indigenous perspectives on disability, and pay our deep respects to the traditional owners and custodians of the land past, present and future. 
Box 1. An overview of the data from the 2015 Survey of Disability, Ageing and Carers (SDAC) on the prevalence and impact of disability among Australia's Aboriginal and Torres Strait Islander peoples (Australian Bureau of Statistics 2017a).

At the time of the 2015 Survey of Disability, Ageing and Carers (SDAC) there were:*

- $\quad$ An estimated 523,200 Aboriginal and Torres Strait Islander people and 22,689,000 non-Indigenous people living in households;

- $\quad$ Of the 523,200 Aboriginal and Torres Strait Islander people, almost one-quarter (23.9\%) reported living with disability, whereas prevalence of disability amongst non-Indigenous people was $17.5 \%$;

- Disability prevalence for Aboriginal and Torres Strait Islander males and females was similar $(22.7 \%$ and $25.1 \%$ respectively);

- $\quad$ One in seven (14.8\%) Aboriginal and Torres Strait Islander people reported living with physical disability (this was the most commonly reported type of disability for Aboriginal and Torres Strait Islander people);

- For Aboriginal and Torres Strait Islander children (aged 0-14 years), intellectual disability (7.0\%) was the most commonly reported disability;

- When compared with non-Indigenous people, Aboriginal and Torres Strait Islander people had significantly higher crude rates of physical disability $(14.8 \%$ compared with $11.4 \%)$, psychosocial disability $(6.6 \%$ compared with $3.8 \%$ ), intellectual disability (5.9\% compared with $2.5 \%)$, and head injury, stroke or acquired brain injury ( $2.1 \%$ compared with $1.1 \%)$.

- When compared with non-Indigenous people, however, there was no significant difference between the reported crude rates of sensory and speech disability in the two populations (6.1\% of Aboriginal and Torres Strait Islander people compared with $5.8 \%$ of non-Indigenous people).

- $\quad$ "Due to the scope of the SDAC, it should be noted that information about Aboriginal and Torres Strait Islander people and non-Indigenous people presented ... is limited to households (and excludes nursing homes and cared-accommodation). The coverage of the SDAC does not include people living in very remote areas and discrete Aboriginal and Torres Strait Islander communities. Therefore, data presented ... are not necessarily representative of all Aboriginal and Torres Strait Islander people living across Australia."

Box 2. Key right to health provisions underpinning this analysis (United Nations General Assembly 2007; United Nations 2006; United Nations General Assembly 1966).

\section{United Nations Declaration on the Rights of Indigenous Peoples}

Article 21(1) Indigenous peoples have the right, without discrimination, to the improvement of their economic and social conditions, including, inter alia, in the areas of education, employment, vocational training and retraining, housing, sanitation, health and social security.

Article 24(1) Indigenous peoples have the right to their traditional medicines and to maintain their health practices, including the conservation of their vital medicinal plants, animals and minerals. Indigenous individuals also have the right to access, without any discrimination, to all social and health services.

Article 24(2) Indigenous individuals have an equal right to the enjoyment of the highest attainable standard of physical and mental health. States shall take the necessary steps with a view to achieving progressively the full realization of this right.

Article 29(3) States shall also take effective measures to ensure, as needed, that programmes for monitoring, maintaining and restoring the health of indigenous peoples, as developed and implemented by the peoples affected by such materials, are duly implemented.

CRPD

Article 25 States parties recognize that persons with disabilities have the right to the enjoyment of the highest attainable standard of health without discrimination on the basis of disability. States Parties shall take all appropriate measures to ensure access for persons with disabilities to health services that are gender-sensitive, including health-related rehabilitation.

ICESCR

Article 12(1) The States Parties to the present Covenant recognize the right of everyone to the enjoyment of the highest attainable standard of physical and mental health. 


\section{Background}

\section{A Brief Overview of Indigenous Imprisonment in Australia}

Thirty-eight thousand, eight hundred and forty-five Australian adults were incarcerated at 30 June 2016; 208 persons per 100,000 population (Australian Bureau of Statistics 2017b). Indigenous Australians are imprisoned at a higher rate than non-Indigenous Australians, with Australia's First Peoples comprising 2.8\% of the Australian adult population but 28\% of the adult full-time prisoner population (Australian Bureau of Statistics 2017b, 2017c). This percentage varies markedly across Australia's eight states and territories. In 2016 in Victoria, for example, it was estimated that $8 \%$ of the prisoner population were of Indigenous background, whereas almost $84 \%$ of the prisoner population in the Northern Territory were of Indigenous heritage (Table 1) (Australian Bureau of Statistics 2017d). The rate of incarceration of Indigenous Australians is increasing-the Indigenous imprisonment rate increased by 7\% between the March quarters of 2016 and 2017 (Australian Bureau of Statistics 2017c). Indigenous Australians are more likely to cycle in and out of prison than the non-Indigenous population (Baldry and Cunneen 2014).

Since British seizure of the Australian continent began in the late 1700s, the Aboriginal and Torres Strait Islander peoples, who are part of the oldest continuing culture in the world (Australian Geographic 2011), have experienced a collective history of rights violations including forced dislocation and invasion, violence, discrimination, and oppression (Maddison 2013; Branco 2013; Human Rights and Equal Opportunity Commission 1997). In light of the last, and the consequential intersecting effects of intergenerational trauma (Tighe et al. 2015; Walters 2011; O'Loughlin 2009), Indigenous Australians' over-representation in the Australian prison system and their higher rate of cycling or transitioning in and out of prison must be both embedded and contextualized (Blagg 2008; Cunneen et al. 2013). Yet being imprisoned is another added form of the already layered and complex trauma experience for Indigenous Australian prisoners; another factor to detrimentally impact on Indigenous Australian prisoner's health and well-being (The SPRINT Project Team 2013). Therefore, "given that Indigenous Australians are already overrepresented in custody and continue to endure the deleterious impacts of colonization, it is important that their specific needs are safely managed in a culturally responsive manner" (Shepherd et al. 2017) —and we would emphasize, in a rights-based manner.

Table 1. Indigenous incarceration rates by state and territory, Australia, 2016 (Australian Bureau of Statistics 2017d).

\begin{tabular}{cccc}
\hline State or Territory & Indigenous Prisoners & All Prisoners & Percent Indigenous \\
\hline New South Wales & 3037 & 12,629 & 24.0 \\
Queensland & 2461 & 7746 & 31.8 \\
Victoria & 535 & 6522 & 8.2 \\
Western Australia & 2403 & 6329 & 38.0 \\
South Australia & 571 & 2948 & 19.4 \\
Northern Territory & 1393 & 1666 & 83.6 \\
Tasmania & 92 & 569 & 16.2 \\
Australian Capital Territory & 105 & 441 & 23.8 \\
\hline
\end{tabular}

It follows that Indigenous prisoners are incarcerated in each one of Australia's 112 custodial facilities (as of 30 June 2016) (Steering Committee for the Review of Government Service Provision 2017). Eighty-six of these facilities are government operated, nine privately operated, and the remainder are transitional centres, a periodic detention centre, and court cell complexes (Steering Committee for the Review of Government Service Provision 2017). The management of prisons is a state and territory, rather than Commonwealth, responsibility (we note Australia is a Federation comprising six states and two mainland territories). Consequently, information on prisons is dispersed across and within state and territory government official publications. 


\section{Prisoner Health in Australia, Including the Health of Prisoners with Intellectual Disability}

This article cannot comprehensively consider the unique health, wellbeing, needs and rights of Indigenous Australians with intellectual disability in the Australian prison system without reviewing two key intersectional, contextual elements. The first element is the broader status of prisoner health in Australia while the second element is narrower in its focus, and requires overview of the specific status of the health and wellbeing of persons with intellectual disability in prisons in Australia.

\subsection{General Impact of the Prison Environs on, and Typology of Health Conditions of, Prisoners Incarcerated in Australia}

As information on prisons is found disseminated among the publications of Australia's state and territory governments, it is unsurprising that official government reports lack consistency and are thus selective regarding reporting of prison conditions. For instance, the Queensland Department of Justice and Attorney-General Annual Report (2015-2016) states that the Department "assists crime prevention through the humane containment, supervision and rehabilitation of offenders in correctional centres ..." ", but provides no specific information on prison conditions (Department of Justice and Attorney-General, Queensland Government 2016). However, a Queensland government website states that nearly all prison cells house one prisoner and contain a toilet, shower and bed (Queensland Government 2014).

As the number of prisoners in Australia has increased (notably between the years of 2005 and 2015- see Table 2), it can be deduced that crowding worsens prison conditions. This was highlighted in a report by the Western Australian Inspector of Custodial Services in 2016 (Morgan 2016). Accordingly, under Australian standards set in 1990, the floor space for a single cell with toilet and shower should be at least 8.75 square metres (Victorian Office of Corrections 1990). However, the Inspector of Custodial Services found that older Western Australian prisons fail to meet this standard (Hakea and Bandyup prisons have cell sizes 5.1 to $6.4 \mathrm{~m}^{2}$ ), and even the newer facilities fall short (Morgan 2016). Consequent holding of two or more prisoners in a single cell "results in a loss of human dignity, affects the ability of people to prepare for court, impacts on rehabilitation, and increases risks to personal safety" (Morgan 2016).

Table 2. Incarceration in Australia by state and territory, 2005 and 2015 (Australian Bureau of Statistics 2017b).

\begin{tabular}{ccccccc}
\hline & \multicolumn{3}{c}{$\mathbf{2 0 0 5}$} & \multicolumn{2}{c}{$\mathbf{2 0 1 5}$} \\
\cline { 2 - 7 } State or Territory & Prisoners & $\begin{array}{c}\text { Percent } \\
\text { Female }\end{array}$ & Population & Prisoners & $\begin{array}{c}\text { Percent } \\
\text { Female }\end{array}$ & Population \\
\hline New South Wales & 9706 & 7 & 6.77 million & 11,797 & 7 & 7.62 million \\
Victoria & 3692 & 7 & 5.02 million & 6219 & 7 & 5.94 million \\
Queensland & 5354 & 7 & 3.96 million & 7318 & 10 & 4.78 million \\
Western Australia & 3482 & 8 & 2.01 million & 5555 & 9 & 2.59 million \\
South Australia & 1473 & 6 & 1.54 million & 2732 & 6 & 1.70 million \\
Tasmania & 551 & 5 & 485,300 & 519 & 6 & 516,600 \\
Australian Capital Territory & 162 & 5 & 325,200 & 396 & 4 & 390,700 \\
Northern Territory & 820 & 3 & 202,800 & 1593 & 9 & 244,300 \\
\hline
\end{tabular}

High risk behavior, especially substance abuse, is also common among prisoners. In New South Wales (NSW), 33.6\% of prisoners injected drugs in prison, although only $6 \%$ reported this behavior (Dolan et al. 2010; Australian Institute of Health and Welfare 2015). Eighteen and four percent of those entering and leaving prison reported sharing needles before or during their current episode of incarceration, respectively, and only 3\% received replacement therapy for opioid dependence while in custody (Australian Institute of Health and Welfare 2015). Large proportions of people entering and leaving Australian prisons, 39 and 58\% respectively, report alcohol consumption at a level placing them at high risk of harm; only $3 \%$ reported alcohol consumption in prison, but similar to drug abuse, 
there is a high likelihood this would not be disclosed (Australian Institute of Health and Welfare 2015). Australia generally has a low prevalence of tobacco consumption, yet $74 \%$ of those entering prison smoke while some jurisdictions-Queensland, for example-prohibit smoking in prison (Queensland Government 2014; Australian Institute of Health and Welfare 2015, 2017).

Including drug and alcohol abuse, $49 \%$ of Australian prison entrants have been told by a health professional that they have a mental health disorder (Australian Institute of Health and Welfare 2015). Among prisoners entering and exiting prison, the proportion with high or very high levels of psychological distress measured using the Kessler 10 scale is $31 \%$ and $19 \%$, respectively (Australian Institute of Health and Welfare 2015). Twenty-three percent of prisoners receive medication for a mental health issue while in prison (Australian Institute of Health and Welfare 2015). There were 53 deaths in custody during 2012 and 2013, 13 allegedly self-inflicted (Australian Institute of Health and Welfare 2015). Sexual assault also occurs in prison, and while only 3\% of prisoners report such assault, it is likely most sexual assault goes unreported, and is associated with psychological distress (Australian Institute of Health and Welfare 2015; Schneider et al. 2011).

The prevalence of Hepatitis B and Hepatitis C is concerning: at prison entry, $18 \%$ and $31 \%$ of prisoners tested positive for Hepatitis B and C, respectively (Australian Institute of Health and Welfare 2015). Prisoners frequently move in and out of prisons, and as well as a high proportion of prisoners having Hepatitis C on entry, the risk of infection in prison is substantial, with an incidence of 34.2 per 100 persons found in one NSW study alone (Dolan et al. 2010; Australian Institute of Health and Welfare 2015; Australian Bureau of Statistics 2010). Other than asthma (25\%), there is low reported diagnosis of non-communicable diseases (NCDs) in the Australian prison populace, with ten, six and four percent of prison entrants reporting ever having been diagnosed respectively with arthritis, cardiovascular disease and diabetes (Australian Institute of Health and Welfare 2015). The prevalence of acquired brain injury (ABI) in Australian prisons, on the other hand, is high (Durand et al. 2017).

\subsection{What Is Broadly Known about Persons with Intellectual Disability in Prisons in Australia}

It is against this complex and worrying health landscape that persons with intellectual disability, including Indigenous Australians with intellectual disability, find themselves in the contemporary Australian prison system. A key challenge, however, is identifying the prevalence of intellectual disability among prison inmates, not only in Australian prisons but prisons worldwide. Reports of the prevalence of intellectual disability among prisoners differ significantly across studies. This is mainly due to flawed research designs to identify intellectual disability, as well as inconsistent use of research methods or inconsistent use of terminology (McBrien 2003). One recent systematic review of the literature on the prevalence of intellectual disability among prisoners reaffirmed that the prevalence rates of intellectual disability among prison populations significantly varied (Hellenbach et al. 2017). That literature review found, for example, that a study on Israeli prison inmates had the highest positive score for intellectual disability at $69.6 \%$, while the lowest prevalence was reported in a United Kingdom study, where $4 \%$ of participants identified as having an intellectual disability (Einat and Einat 2008; Hassiotis et al. 2011).

What is confirmed is that people with intellectual disability are over-represented in prisons internationally (Fazel et al. 2008). In the Australian context, it is estimated nine to $10 \%$ of prisoners about to be released experience intellectual disability (Dias et al. 2013). Unsurprisingly, little is known about the prevalence of intellectual disability and cognitive impairment among Indigenous Australian inmates, although there are higher levels among Indigenous than non-Indigenous inmates (Dias et al. 2013; Simpson and Sotiri 2004; Frize et al. 2008; Holland and Persson 2007; Baldry et al. 2012; Haysom et al. 2014; Bhandari et al. 2014). One main reason that prevalence rates are particularly unclear in Indigenous Australians with intellectual disability (and hence those in incarceration) according to Balaratnasignam, is because, "overall, most psychometric instruments developed for cognitive assessments in Indigenous Australian populations have been inadequately validated" (Balaratnasingam and Roy 2015). Accordingly: 
"There are many difficulties in making a diagnosis of ID [intellectual disability] in Indigenous people. It is important to note that tests used in the assessment of general intelligence are rarely culture-free and could have contributed to the over representation of Indigenous Australians among those considered to have an ID ... Almost all IQ tests are culturally biased against minority groups, including Indigenous Australians ..." (Roy and Balaratnasingam 2014).

Prisoners with intellectual disability frequently experience mental health disorders and complex comorbid chronic physical conditions, while substance misuse among prisoners with intellectual disability (as among the general prison population) is allegedly common (Dias et al. 2013, 2014; Bhandari et al. 2014; Männynsalo et al. 2009; Alexander et al. 2011; Boer et al. 2016). In addition, "Those with intellectual disability are likely to experience greater difficulty coping in prisons and to be vulnerable to bullying and financial, physical and sexual abuse" (Boer et al. 2016). They are also far more powerless in related situations in the criminal justice system; engendering the increased likelihood of criminal justice system contact, unequal recognition before the law and, ultimately, injustice. Respect for the social model of disability approach, which underlies and is fundamental to the CRPD, is frequently denied prisoners with intellectual disability by prison and legal systems, and those in authority and power who run them (who may or may not have received formal training on the CRPD). For instance, persons in custody with intellectual disability regularly face court proceedings and interrogative questioning (etc.) in a physical, attitudinal, communication and social environment infused with structural and other potential unlawful barriers. In such a discriminatory, isolating and overwhelming environment with entrenched power differentials, the medical model of disability approach is ordinarily rife and normalized (i.e., disability is viewed as 'the problem' of the individual, completely counter the CRPD and social model of disability). Dehumanizing and devaluing criminal justice and prison system environments do not enable people with disabilities a right to fully participate on an equal basis with others, and can exacerbate persons with disabilities ability to communicate and express themselves freely (including giving free and informed consent), increase the individual's exposure to a high degree of suggestibility and situations wherein their decision-making capacity is impaired, or impact persons with disabilities ability to seek-out appropriate legal representation, advocacy, and other vital supports that would enable key civil, political, economic, and (significantly in the case of Indigenous Australians) social and cultural rights (Clare and Gudjonsson 1993; Bhaumik et al. 2016; Vanny et al. 2008; Simpson 2014; Australian Human Rights Commission 2014; Cockram 2005).

\section{Impact of Imprisonment on Indigenous Australians with Intellectual Disability and Their Health and Wellbeing}

Indigenous Australians who have been in the prison environment are likely to experience a number of long-term health issues (Indig et al. 2010). They are also likely to be at a high risk of injury and illness following their release from custody (Stewart et al. 2004; Alan et al. 2011). It follows that the health and wellbeing of Indigenous prisoners with intellectual disability must be nested within this context. However, the specific needs of Indigenous people in custody with intellectual disability and cognitive impairments are not only poorly understood, but the importance of the social and emotional wellbeing of Aboriginal and Torres Strait Islander inmates with intellectual disability has purportedly not been given "any substantive consideration" (Shepherd et al. 2017; Maxwell et al. 2013).

On the other hand, possibly the most insightful empirical research into the health of Indigenous Australian prisoners with cognitive impairment was conducted in 2012 by Shepherd and colleagues who interviewed 122 adult Indigenous inmates remanded or sentenced in Victorian prisons (Shepherd et al. 2017). Shepherd and colleagues found that participants with cognitive impairment were more likely to report having an illness or disability over the past 12 months, with "[a] diminished level of wellbeing for cognitively impaired Indigenous participants" (Shepherd et al. 2017). In that study cognitive impairment was also found to be associated with: 
"Poorer coping mechanisms [of Indigenous prisoners with cognitive impairment], additional experiences of racism, difficulties handling emotions, discomfort around non-Aboriginal people and reduced access to culturally meaningful activities in custody ..." (Shepherd et al. 2017).

Based on their findings, Shepherd and colleagues further concluded that "Possessing a cognitive disability in such environs with limited supports and inaccessible specialized services would increase the risk of problem behaviors such as alcohol and drug abuse" (Shepherd et al. 2017).

It follows that individual cases of incarceration of Indigenous Australians with intellectual disability, and the negative incarceration experience on their health, have achieved national and international prominence. In 2012, for instance, Rosie Ann Fulton, a 23-year-old Indigenous woman with intellectual disability resulting from fetal alcohol spectrum disorder, faced driving charges in Western Australia. Considered unfit for trial, she was detained under Western Australian state forensic mental health legislation, and because she was deemed unfit for community release she was kept in prison. She spent the next two years incarcerated though unconvicted. It was when her indefinite detention received national media scrutiny and public outcry (a petition for her release attracted 120,000 signatures) that she was released (Stewart 2014).

The indefinite detention of Rosie Ann Fulton was not, however, an isolated incidence. Marlon Noble, an Indigenous man with intellectual disability, because he was not fit to stand trial under Western Australian law could "be detained in prison-indefinitely and without trial" (McGaughey et al. 2017). Marlon Noble's case attracted international attention -in that case, the UN Committee on the Rights of Persons with Disabilities considered Australia had "breached its obligations under the UN Convention on the Rights of Persons with Disabilities" (McGaughey et al. 2017). However, it is not known how many other Indigenous Australians with intellectual disability are presently in indefinite detention, without independent review, in prisons around Australia-but it is known that they are there (Steele 2016a; Zillman 2016; Steele 2016b; Goodna and Innes 2014; Sotiri et al. 2012).

Both Rosie Ann Fulton and Marlon Noble's cases of indefinite detention highlight a number of significant issues regarding Indigenous Australian prisoners with intellectual disability-and the multiple human rights breaches underlying their experiences will be dealt with in the following section. However, what their experience demonstrates is not only the lack of support for Indigenous Australians with intellectual disability in the Australian criminal justice and prison system generally, but the overwhelming lack of supported and culturally appropriate community placements available once such persons, with often complex histories and needs, transition from detention into the community. In turn, this lack of support for former Indigenous prisoners with intellectual disability contributes to the real risk of their recidivism (or re-institutionalisation) and return to incarceration. This was sadly highlighted in Rosie Ann Fulton's case, where, on her return home to the Northern Territory, she was arrested for assault and was placed in custody in Alice Springs (Maddocks 2016).

\section{Suggestions and Conclusions}

The prima facie incarceration of Indigenous Australians with intellectual disability in the mainstream Australian prison system presents as a confluence of multiple and intersecting apparent human rights violations, which ultimately results in a lack of due process, equal recognition before the law, as well as accountable, transparent and culturally responsive processes and outcomes. Moreover, and all too frequently for Indigenous Australians with intellectual disability, these apparent rights violations tremendously contribute to cycles, lives and life times of injustice, as can be seen in the extreme cases of Marlon Noble and Rosie Ann Fulton.

However, it is erroneous to posit this as a matter of disability or justice alone; it is a matter of respect for fundamental human dignity and human rights of all Indigenous Australians with intellectual disability, and particularly those Indigenous Australians with intellectual disability and cognitive impairment in the criminal justice and prison system. Indeed, protection, promotion and 
fulfilment of the highest attainable standard of physical and mental health ("right to health") for Indigenous Australian prisoners with intellectual disability-as the Noble and Fulton cases exemplify-can shift well beyond the parameters of right to health breaches that fall within the scope of economic social and cultural rights violations. Rather, cross-cutting civil and political rights violations are arguably broadly occurring, in breach of Australia's immediate obligations under Article 7 of the International Covenant of Civil and Political Rights (International Covenant of Civil and Political Rights ICCPR) and the jus cogens prohibition against torture and other cruel, inhuman or degrading treatment or punishment (International Covenant of Civil and Political Rights ICCPR; Parker 1989).

Indeed, the Noble and Fulton cases precipitated the Commonwealth Senate Inquiry into the Indefinite Detention of People with Cognitive and Psychiatric Impairment in Australia in late 2015, with the Senate's Community Affairs References Committee ("the Senate Committee") releasing its report in November 2016 (Parliament of Australia Australian Government). Tellingly, the Senate Committee issued 32 recommendations (Appendix A) (Parliament of Australia Australian Government). A number of these recommendations specifically referred to Aboriginal and Torres Strait Islanders with cognitive and psychiatric impairment, such as recommendations seven, 13, and 14 . These recommendations focus on the "special circumstances" of Indigenous detainees with cognitive and psychiatric impairment (including those in the prison system), and the need for access to culturally appropriate therapeutic and support services that can be deployed by service providers, police and the judiciary, as well as raising the need for specialist courts for Aboriginal and Torres Strait Islander peoples, particularly in remote parts of Australia.

While the identification of the issues (and remedies) contained in the Senate Committee's 32 recommendations are to be lauded, there are three major challenges with regard to their implementation. Firstly, the language of the recommendations should extend to expressly include persons with intellectual disability, not only persons with cognitive and psychiatric impairment. The second challenge is that the Senate Committee is dependent on the governments of the states and territories to implement the suite of recommendations: "9.6 The committee acknowledges that it is the states and territories that have primary carriage of forensic legislation, and the delivery of corrective services and disability services" (Parliament of Australia Australian Government). This is inherently problematic: states and territories are under no legal obligation to implement the recommendations, or can indeed cherry-pick the recommendations as the government of the day sees fit.

The third major challenge to implementation is that the content of the 32 recommendations speaks to, and must marry with, the full spectrum of civil, political, economic, social, and cultural rights contained in international human rights law, and Australia's many obligations under international human rights law. This is also recognised by the Senate Committee: "As a signatory of the Disability Convention, the Australian Government is responsible for ensuring the treatment of people with disability in Australia is compatible with the provisions of the Convention" (Parliament of Australia Australian Government). However, Australia is the only western liberal democracy in the world without a human rights act, bill of rights, or similar instrument (including lack of constitutional rights recognition). Furthermore, the Australian Government is unlikely to entertain a potential Federal Human Rights Act in the foreseeable future: both sides of government rejected the National Human Rights Consultation Committee's (NHRCC) recommendation in 2009, following the largest public consultation in Australia's history, that the Australian government adopt a Federal Human Rights Act (National Human Rights Consultation Committee NHRCC; Parliament of Australia Australian Government). Therefore, much onus for facilitation of a human rights landscape and culture in the Australian context falls onto the state and territory governments.

Whether the rights-based content of the Senate Committee's 32 recommendations could or would find intersecting remedy and legal enforcement at the state or territory level in human rights law is, again, inconsistent and problematic. Of Australia's federation of six states and two territories, only the Australian Capital Territory (ACT) has passed human rights legislation by way of its Human 
Rights Act 2004, and Victoria has also passed a human rights charter, the Charter of Human Rights and Responsibilities Act 2006 (Government of the Australian Capital Territory ACT; Government of Victoria 2006). The Queensland government is considering a Human Rights Act for Queensland, but similar to the Victorian model, Queensland's would include civil and political rights only (we note that the ACT model has a very distilled version of economic, social and cultural rights through its inclusion of the right to education) (Government of the Australian Capital Territory ACT; Human Rights Law Centre 2016). However, it is the two jurisdictions that the Senate Committee frequently refers to within the 32 recommendations (and in which many marginalised Indigenous Australians reside) -Western Australia and the Northern Territory - that are without state or territory human rights acts.

Moreover, even though the states and territories have carriage for implementing the 32 recommendations, the Senate Committee acknowledges "[t]his does not absolve the Australian Government of any responsibility in this area" (Parliament of Australia Australian Government). The Senate Committee emphasizes "The Australian Government must do more than simply facilitate a response from the relevant state government to the UN [i.e., UN Committee on the Rights of Persons with Disabilities]" (Parliament of Australia Australian Government). Therefore, in recommendation one the Senate Committee highlights "the Australian Government [must] work with state and territory governments on the implementation of initiatives to improve access to justice for people with disability ..." (Parliament of Australia Australian Government). However, this instruction is weak because it is rooted in policy, not cogently and unequivocally grounded in law. Here it is also worthwhile noting that the CRPD Committee recommendations in relation to Marlon Noble were directed to the Australian government, which does not appear to have a direct mechanism to force the state of Western Australia to change its relevant laws and heed the CRPD Committee's directives.

The Senate Committee's frustration that the content of its lengthy recommendations are unlikely to be taken seriously at the national or state/territory operationalization level is palpable in the introductory paragraphs of the recommendations section of its November 2016 report. The Senate Committee notes that although this is "the first major inquiry" to specifically examine the question of indefinite detention of people with cognitive or psychiatric impairment (which includes persons with intellectual disability), the Senate Committee considers this inquiry would likely not have been needed had the states and territories implemented the recommendation from other prior inquiries or reports with respect to broader disability, mental health and justice issues: "[and] had they [the recommendations and outcomes] been fully implemented they would have largely addressed many of the causes of indefinite detention of people with cognitive and psychiatric impairment" (Parliament of Australia Australian Government). Here, the Senate Committee refers to the recommendations found within three important documents: (1) Community Affairs Committee, 'Violence, abuse and neglect against people with disability institutional and residential settings' of November 2015 (Parliament of Australia Australian Government); (2) Australia Law Reform Commission report, 'Equality, Capacity and Disability in Commonwealth Laws' of August 2014 (Australian Law Reform Commission Australian Government); and (3) the Australian Human Rights Commission report, 'Equal before the law: towards disability justice strategies' of February 2014 (Australian Human Rights Commission 2014).

Therefore, and in light of the above, the biggest barrier to improving the health and wellbeing of Indigenous Australians with intellectual disability in Australian prisons, and for such prisoners to avoid repeated incarceration (or re-institutionalisation) and subjection to complex psychological trauma (that compounds intergenerational and other trauma), and lack of due process and greater injustice, remains one of governance and accountability. Advocates for the health and human rights of Indigenous Australians with intellectual disability in Australian prisons are walking in circles without compelling national, state and territory human rights law that they can leverage to promote and realize the very human dignity of this highly marginalized prisoner populace that frequently presents with culturally specific, complex needs (Brolan et al. 2011). Clearly, Federal 'policy recommendations' that may or may not be taken up by state and territory governments are arguably inadequate. Therefore, 
ongoing, vigorous advocacy for state and territory governments to enact human rights legislation that includes economic, social and cultural rights is required. However, this is a long and time-intensive road in a country that lacks, broadly speaking, a human rights culture at the federal level. An excellent start would have been the Australian Government's adoption of the 'Uluru Statement from the Heart' of May 2017 and its call for Federal Parliament to establish a permanent Indigenous advisory body; which was rejected by Prime Minister Malcolm Turnbull six months later (Australian Human Rights Commission Australian Government; Referendum Council 2017; Brennan 2017).

Vigorous advocacy efforts should pointedly and affirmatively push for integrating de facto commitment to the UN Declaration on the Rights of Indigenous Peoples at all levels of Australian government, and through and in all relevant law and policy in Australia. Better information and data, and greater transparency, on intellectual disability in imprisoned Indigenous Australians, including the lived experiences, health and wellbeing of those released from prison, and ensuing inter-related experiences of access to justice (and injustice), is also essential. This is because a strong evidence base to underpin advocacy efforts is needed. Here, not only is quality and reliable quantitative prevalence data required on Aboriginal and Torres Strait Islander persons with intellectual disability in Australian prisons, but of equal importance will be evidence and lived experiences of access to justice and experiences of injustice and lack of due process acquired through qualitative research.

Certainly, qualitative research that is community-based and participatory and led by Indigenous researchers, which engages with Indigenous Australians with intellectual disability within and outside of the prison system, as well as with supporters and service providers, will be crucial. Exploring, documenting and understanding the lived experiences of Indigenous Australians with intellectual disability currently and formerly in the Australian prison system (including investigating understandings of health, well-being and human rights (and potential rejection of Western notions of rights)), and enabling their aspirations and self-determination to frame and lead research processes and analyses, will be key (Yap and Yu 2016; Gale 2016; Lee 2016; Mazel 2016; Holcombe 2015). This is in line with the central principle underlying disability-inclusive development: Nothing about us without us. A national approach with harmonization of state laws impacting on Indigenous people with intellectual and developmental disability and incorporating the lessons learned from the Noble and Fulton cases will be further pivotal, as will adequately funded and culturally appropriate legal and custodial programs and services for Indigenous Australians with intellectual disability to (a) avoid incarceration, (b) protect, promote and fulfil the rights of prisoners with intellectual disability, (c) assist with reintegration post-imprisonment and avoid repeated incarceration, and (d) progress the rights of Indigenous Australians with intellectual disability to due process and equal recognition before the law, culturally responsive service provision and ultimately, just outcomes.

Acknowledgments: Claire E. Brolan gratefully acknowledges the support of her Postdoctoral Research Fellowship at the Dalla Lana School of Public Health, University of Toronto.

Author Contributions: Claire E. Brolan and David Harley conceived this manuscript. Claire E. Brolan completed the review of the literature and David Harley developed the first draft paper. Both authors contributed to manuscript redrafts and approved all sections.

Conflicts of Interest: The authors declare no conflict of interest.

\section{Appendix A. Senate Community Affairs References Committee's List of 32 Recommendations (November 2016)}

\section{Recommendation 1}

9.11 The committee recommends the Australian Government work with state and territory governments on the implementation of initiatives to improve access to justice for people with disability contained in the reports by the Law Reform Commission, Equality, Capacity and Disability in Commonwealth Laws, the Human Rights Commission, Equal Before the Law and Productivity Commission, Access to Justice Arrangements, with particular focus on: 
- better intervention and support services;

- $\quad$ expanded Community Visitor's schemes;

- improved witness support services to people with disabilities;

- creation of an assessment protocol that assists police, courts, and correctional institutions in identifying people with disabilities. Where identified, a trained officer will provide support;

- transparent, effective and culturally appropriate complaints handling procedures;

- training for police, lawyers and others in justice in needs of people with disability; and

- where a person who has been found unfit to plead is to be held in detention, demonstrate that all reasonable steps have been taken to avoid this outcome, and that person must be held in a place of therapeutic service delivery.

\section{Recommendation 2}

9.12 The committee also recommends that each state and territory implement a Disability Justice Plan.

\section{Recommendation 3}

9.13 The committee believes that there is a need for further investigation of access to justice issues, with a focus on:

- the implementation requirements for supported decision-making;

- investigating the potential for the United Kingdom system of registered intermediaries; and

- the indefinite detention of people with cognitive impairment or psychiatric disabilities.

\section{Recommendation 4}

9.15 The committee recommends the Australian Government work with state and territory governments on a nationally consistent approach to existing state and territory disability oversight mechanisms, to include;

- increased funding for community visitor schemes, with consideration these schemes be professionalised in all jurisdictions and with a mandatory reporting requirement for suspected violence, abuse or neglect; and

- greater crossover in oversight and complaints mechanisms between aged care and disability.

9.16 A nationally consistent approach to disability oversight mechanisms is best overseen by the national disability watchdog.

\section{Recommendation 5}

9.18 The committee recommends that the Australian Government drive a nationally consistent move away from substitute decision-making towards supported decision-making models.

\section{Recommendation 6}

9.19 The committee recommends that the Australian Government work with state and territory governments to implement the recommendations of the Australian Law Reform Commission report Equality, Capacity and Disability in Commonwealth Laws, in relation to legal capacity and supported decision-making.

\section{Recommendation 7}

9.20 The committee recommends the Australian Government work with state and territory governments to create national consistency in the administration of guardianship laws to ensure: 
- public advocate and guardianship functions are separate to ensure independent oversight;

- mandatory training on supported decision-making for guardians;

- that service delivery organisations or accommodation providers are never given guardianship;

- automatic increased oversight where service delivery organisations or accommodation providers recommend families lose guardianship; and

- that Aboriginal and Torres Strait Islander peoples' particular circumstances are taken into account in developing guardianship systems.

\section{Recommendation 8}

9.24 The committee recommends that the forthcoming national statement of principles adopt the position that indefinite detention is unacceptable and that state and territory legislation be amended in line with this principle.

- The committee recommends that the Law, Crime and Community Safety Council (LCCSC) endorse and adopt the National Principles at its earliest opportunity.

\section{Recommendation 9}

9.25 The committee recommends that the LCCSC complete its data collection project at its earliest opportunity.

\section{Recommendation 10}

9.27 The committee recommends that the Council of Australian Governments (COAG) develop and implement a disability screening strategy (including hearing assessments) for all Australian jurisdictions. This screening strategy would apply to all people (adults and minors) who engage with the criminal justice system. The strategy would be applied at multiple points throughout the criminal justice system such as first contact with police, courts, prisons and related facilities.

\section{Recommendation 11}

9.29 The committee recommends that the COAG work together to ensure that recently developed tools such as the Fetal Alcohol Spectrum Disorder (FASD) diagnosis tool are provided as a supported resource to police, courts, legal aid and other related groups.

\section{Recommendation 12}

9.31 The committee recommends that the Australian Government, through the COAG, actively encourage support worker programs which assist people with cognitive and psychiatric impairment to engage with and participate in the court process. The Australian Government should work closely with the states and territories to identify suitable programs to be funded for expansion where they are currently being trialled, and establish new programs where they currently do not exist.

\section{Recommendation 13}

9.33 The committee recommends that COAG develop a range of culturally appropriate resources for Aboriginal and Torres Strait Islander peoples that can be deployed to service providers, police and the judiciary. These resources will assist the service providers, police and the judiciary to communicate more effectively with Aboriginal and Torres Strait Islander peoples engaged in the criminal justice system.

9.34 The committee recommends that the Australian Government, through COAG, fund a number of Aboriginal and Torres Strait Islander identified support worker positions across a number of population centres, particularly in the Northern Territory and Western Australia. This would include positions or funding for signing and translation services. 
9.35 The committee recommends that Aboriginal controlled organisations should be resourced to provide specialised and culturally appropriate support to Aboriginal and Torres Strait Islander peoples with cognitive and psychiatric impairments in detention and community care.

\section{Recommendation 14}

9.37 The committee recommends that the COAG work together to modify guidelines for police interrogation of Aboriginal and Torres Strait Islander peoples in each state and territory to include a requirement that a hearing assessment be conducted for any Aboriginal and Torres Strait Islander person who is having communication difficulties, irrespective of whether police officers consider that the communication difficulties arise from language and crosscultural issues.

\section{Recommendation 15}

9.40 The committee recommends that the COAG consider an appropriate mechanism for jurisdictions with specialist courts to share their expertise and experience with other jurisdictions.

9.41 The committee recommends that the COAG develop and implement appropriately resourced mobile courts for remote parts of WA and the NT.

\section{Recommendation 16}

9.43 The committee recommends that the COAG ensures a consistent legislative approach across all Australian jurisdictions to provide a range of options for the placement of forensic patients beyond unconditional release and prison.

\section{Recommendation 17}

9.45 The committee recommends that the COAG ensures a consistent legislative approach with respect to limiting terms for forensic patients in all Australian jurisdictions.

\section{Recommendation 18}

9.46 The committee recommends that the COAG works together to cease the use of mandatory sentencing.

\section{Recommendation 19}

9.49 The committee recommends that the LCCSC extend its data collection project to identify and quantify the supply shortfall for forensic accommodation placements in secure care facilities and supported accommodation in the community.

\section{Recommendation 20}

9.51 The committee recommends that the Australian Government work closely with the NT Government to plan, fund and construct non-prison forensic secure care facilities and the acquisition of supported accommodation options in communities across the NT.

9.52 The committee recommends that the Australian Government work closely with the NT Government to ensure that all forensic facilities are appropriately staffed.

\section{Recommendation 21}

9.54 The committee recommends that the COAG ensure that ISPs in all Australian jurisdictions have consistent objectives and are clear on who is responsible for delivery of services, regardless of where a forensic patient is housed.

\section{Recommendation 22}

9.56 The committee recommends that the Australian Government work closely with the NT Government to ensure that its ISP (or equivalent) for forensic patients have clear objectives of 
transitioning a forensic patient from prison to secure care, and where appropriate, from secure care to the community.

\section{Recommendation 23}

9.58 The committee recommends that COAG establish a working group:

- to review existing early intervention programs for people with cognitive and/or psychiatric impairment; and

- develop and implement programs which engage with people with cognitive impairment at the youngest appropriate age.

\section{Recommendation 24}

9.60 The committee recommends that the COAG develop and implement a series of justice reinvestment projects across the country to showcase the longterm social and economic benefits of justice reinvestment.

\section{Recommendation 25}

9.62 The committee recommends that the Joint Standing Committee on the National Disability Insurance Scheme (NDIS) conduct an inquiry into the issue of eligibility and access to the NDIS for people held in prisons and the criminal justice system more broadly.

\section{Recommendation 26}

9.64 The committee recommends that the WA and NT Governments transition forensic patients currently held in prison to the relevant secure care forensic facility in each state as a matter of urgency.

\section{Recommendation 27}

9.67 The committee recommends that state and territory governments facilitate improved first responses to incidents involving people with cognitive or psychiatric impairment by ensuring:

- Police and ambulance officers are provided with appropriate frontline training to recognise and respond to situations involving cognitive or psychiatric impairment issues.

- Police and ambulance officers are provided with specialist resources, such as state-wide $24 / 7$ access to mental health teams to provide immediate advice during first response incidents.

- Increased funding for health transport to ensure that police resources are not used to transport people for mental health assessments.

\section{Recommendation 28}

9.69 The committee recommends that state and territory governments investigate the appropriateness of early intervention mental health treatment, with a specific goal to reduce 'risk-induced' treatment-related detention.

\section{Recommendation 29}

9.71 The committee recommends the Australian Government work with state and territory governments to create national consistency in the approach to compulsory treatment orders, to ensure:

- appropriate 'risk of harm' levels are set for assessments that can result in detention for the purposes of therapeutic intervention;

- mandated requirements for 'least restrictive' treatment;

- regular reviews, including assessment of treatment against therapeutic benchmarks; and

- independent oversight. 


\section{Recommendation 30}

9.73 The committee recommends that state and territory governments consider and implement legislative change to strengthen the effect of supported decision-making tools such as Advance Directives.

\section{Recommendation 31}

9.75 The committee recommends the state and territory governments consider adopting elements of the Victorian disability frameworks.

\section{Recommendation 32}

9.77 The committee recommends that state and territory governments proactively fund the construction or acquisition of a range of appropriate supported accommodation options across metropolitan and regional locations for people with cognitive and/or psychiatric impairments.

\section{References}

Government of the Australian Capital Territory (ACT). 2017. Human Rights Act 2004. A2004-5. Republication No. 12 Effective: 2 March 2017. Available online: http:/ / www.legislation.act.gov.au/a/2004-5/current/pdf/ 2004-5.pdf (accessed on 2 September 2017).

Alan, Janine, Melinda Burmas, David Preen, and Jon Pfaff. 2011. Inpatient hospital use in the first year after release from prison: A Western Australian population-based record linkage study. Australian and New Zealand Journal of Public Health 35: 264-69. [CrossRef] [PubMed]

Alexander, Regi, Avinash Hiremath, Verity Chester, Fatima Green, Ignatius Gunaratna, and Sudeep Hoare. 2011. Evaluation of treatment outcomes from a medium secure unit for people with intellectual disability. Advances in Mental Health and Intellectual Disabilities 5: 22-32. [CrossRef]

Australian Bureau of Statistics. 2010. Australian Social Trends, March 2010. Available online: http:/ /www.abs. gov.au/AUSSTATS/abs@.nsf/Lookup/4102.0Main+Features10Mar+2010 (accessed on 10 July 2017).

Australian Bureau of Statistics. 2017a. 4430.0-Disability, Ageing and Carers, Australia: Summary of Findings, 2015: Aboriginal and Torres Strait Islander People with Disability. Released 20 April. Canberra: Australian Bureau of Statistics, Commonwealth Government of Australia. Available online: http:/ /www.abs.gov.au/AUSSTATS/ abs@.nsf/Lookup/4430.0Main+Features802015?OpenDocument (accessed on 27 August 2017).

Australian Bureau of Statistics. 2017b. Prisoners in Australia-2016. Available online: http://www.abs. gov.au/ausstats/abs@.nsf/Lookup/bySubject/4517.0 2016 MainFeatures Keyfindings 1 (accessed on 7 April 2017).

Australian Bureau of Statistics. 2017c. 4512.0-Corrective Services, Australia, March Quarter 2017. Summary of Findings Persons in Corrective Services, Released 8 June 2017. Available online: http:/ / www.abs.gov.au/AUSSTATS/abs@.nsf/Lookup/4512.0Main+Features1March\%20quarter\% 202017? OpenDocument (accessed on 27 August 2017).

Australian Bureau of Statistics. 2017d. 4517.0—Prisoners in Australia, 2016. Available online: http:/ / www.abs. gov.au/AUSSTATS/abs@.nsf/DetailsPage/4517.02016?OpenDocument (accessed on 6 April 2017).

Australian Geographic. 2011. DNA Confirms Aboriginal Culture One of Earth's Oldest. September 23. Available online: http://www.australiangeographic.com.au/news/2011/09/dna-confirms-aboriginalculture-one-of-earths-oldest/ (accessed on 27 August 2017).

Australian Human Rights Commission. 2014. Equal before the Law: Towards Disability Justice Strategies. Canberra: AHRC. Available online: http://www.humanrights.gov.au/sites/default/files/document/publication/ 2014_Equal_Before_the_Law.pdf (accessed on 27 August 2017).

Australian Human Rights Commission (Australian Government). 2017. About Constitutional Recognition. Available online: https://www.humanrights.gov.au/publications/about-constitutionalrecognition (accessed on 2 September 2017).

Australian Institute of Health and Welfare. 2015. The Health of Australia's Prisoners. Cat. No. PHE 207; Canberra: AIHW. Available online: http://www.aihw.gov.au/WorkArea/DownloadAsset.aspx?id=60129553682 (accessed on 10 July 2017). 
Australian Institute of Health and Welfare. 2017. National Drug Strategy Household Survey (NDSHS) 2016 Key Findings. Available online: http:/ / www.aihw.gov.au/alcohol-and-other-drugs/data-sources/ndshs-2016/ key-findings/ (accessed on 10 July 2017).

Australian Law Reform Commission (Australian Government). 2014. Equality, Capacity and Disability in Commonwealth Laws (Final Report). August. Available online: https:/ /www.alrc.gov.au/sites/default/ files/pdfs/publications/alrc_124_whole_pdf_file.pdf (accessed on 2 September 2017).

Balaratnasingam, Sivasankaran, and Meera Roy. 2015. Intellectual disability in Indigenous Australians: Issues and challenges. Australian Psychiatry 23: 641-43. [CrossRef] [PubMed]

Baldry, Eileen, and Chris Cunneen. 2014. Imprisoned Indigenous women and the shadow of colonial patriarch. Australian and New Zealand Journal of Criminology 47: 275-98. [CrossRef]

Baldry, Eileen, Leanne Dowse, and Melissa Clarence. 2012. People with Intellectual Disability in the Criminal Justice System. NSW Family and Community Services, Ageing, Disability and Home Care. Sydney: University of New South Wales. Available online: https://www.adhc.nsw.gov.au/_data/assets/file/0003/264054/ Intellectual_and_cognitive_disability_in_criminal_justice_system.pdf (accessed on 27 August 2017).

Bhandari, Abhishta, Kate van Dooren, Eastgate Gillian, Lennox Nicholas, and Stuart A. Kinner. 2014. Comparison of social circumstances, substance use and substance-related harm in soon-to-be-released prisoners with and without intellectual disability. Journal of Intellectual Disability Research 59: 571-79. [CrossRef] [PubMed]

Bhaumik, Sabyasachi, Reza Kiani, Dasari Mohan Michael, Shweta Gangavati, Sayeed Khan, Julio Torales, Kenneth R. Javate, and Antonio Ventriglio. 2016. Intellectual disability and mental health: An overview. International Journal of Culture and Mental Health 9: 417-29. [CrossRef]

Blagg, Harry. 2008. Crime, Aboriginality and the Decolonization of Justice. Leichardt: Hawkins Press.

Boer, Harm, Regi Alexander, John Devapriam, Julio Torales, Roger Ng, Joao Castaldelli-Maia, and Antonio Ventriglio. 2016. Prisoner mental health care for people with intellectual disability. International Journal of Culture and Mental Health 9: 442-46. [CrossRef]

Branco, Jorge. 2013. Aboriginal Stolen Wages Lawsuit 'as Important as Mabo' to Go National. 13 September. Available online: https://www.brisbanetimes.com.au/national/queensland/aboriginal-stolen-wageslawsuit-as-important-as-mabo-to-go-national-20160913-grexm8.html (accessed on 27 August 2017).

Brennan, Bridget. 2017. Indigenous Leaders Enraged as Advisory Board Referendum Is Rejected by Malcolm Turnbull. ABC News (Online), October 27. Available online: http:/ /www.abc.net.au/news/2017-10-27/ indigenous-leaders-enraged-by-pms-referendum-rejection/9090762 (accessed on 6 December 2017).

Brolan, Claire E., Robert S. Ware, Miriam Taylor Gomez, and Nicholas G. Lennox. 2011. The right to health of Australians with intellectual disability. Australian Journal of Human Rights 17: 1-32.

Clare, Isabel H., and Gisli H. Gudjonsson. 1993. Interrogative suggestibility, confabulation, and acquiescence in people with mild learning difficulties (Mental handicap): Implications for reliability during police interrogation. British Journal of Clinical Psychology 32: 295-301. [CrossRef] [PubMed]

Cockram, Judith. 2005. Justice or differential treatment? Sentencing of offenders with an intellectual disability. Journal of Intellectual and Developmental Disability 30: 3-13. [CrossRef]

United Nations. 2006. Convention on the Rights of Persons with Disabilities (CRPD). New York: United Nations.

Cunneen, Chris, Eileen Baldry, David Brown, Mark Brown, Melanie Schwartz, and Alex Steel. 2013. Penal culture and hyper incarceration: The revival of the prison. In Penal Culture: Transmission, Normalisation and Reproduction. Edited by D, Nelken. Surrey: Ashgate Publishing Limited.

Dias, Shannon, Robert S. Ware, Stuart A. Kinner, and Nicholas G. Lennox. 2013. Physical health outcomes in prisoners with intellectual disability: A cross-sectional study. Journal of Intellectual Disability Research 57: 1191-96. [CrossRef] [PubMed]

Dias, Shannon, Robert S. Ware, Stuart A. Kinner, and Nicholas G. Lennox. 2014. Co-occuring mental disorder and intellectual disability in a large sample of Australian prisoners. Australian and New Zealand Journal of Psychiatry 47: 938-44. [CrossRef] [PubMed]

Dolan, Kate, Suzy Teutsch, Nicolas Scheuer, Michael Levy, William Rawlinson, John Kaldor, Andrew Lloyd, and Paul Haber. 2010. Incidence and risk for acute hepatitis C infection during imprisonment in Australia. European Journal of Epidemiology 25: 143-48. [CrossRef] [PubMed]

Durand, Eric, Mathilde Chevignard, A. Ruet, A. Dereix, C. Jourdan, and Pascale Pradat-Diehl. 2017. History of traumatic brain injury in prison populations: A systematic review. Annals of Physical and Rehabilitation Medicine 60: 95-101. [CrossRef] [PubMed] 
Einat, Tomer, and Amela Einat. 2008. Learning disabilities and delinquency: A study of Israeli prison mates. International Journal of Offender Therapy and Comparative Criminology 52: 416-34. [CrossRef] [PubMed]

Fazel, Seena, Kiriakos Xenitidis, and John Powell. 2008. The prevalence of intellectual disabilities among 12,000 prisoners-A systematic review. International Journal of Law and Psychiatry 31: 369-73. [CrossRef] [PubMed]

Frize, M., D. Kenny, and C. Lennings. 2008. The relationship between intellectual disability, Indigenous status and risk of reoffending in juvenile offenders on community orders. Journal of Intellectual Disability Research 52: 510-19. [CrossRef] [PubMed]

Gale, Peter. 2016. Rights, responsibilities, and resistance: Legal discourse and intervention legislation in the Northern Territory in Australia. Semiotica 209: 167-85. [CrossRef]

Goodna, Mick, and Graeme Innes. 2014. Jailed without Conviction: Send Rosie Anne Fulton Home. The Guardian (Australian Edition) (Online). March 14. Available online: https:/ /www.theguardian.com/commentisfree/ 2014/mar/14/jailed-without-conviction-send-rosie-anne-fulton-home (accessed on 27 August 2017).

Government of Victoria. 2006. Charter of Human Rights and Responsibilities Act. Act No. 43/2006. Available online: http://www.legislation.vic.gov.au/Domino/Web_Notes/LDMS/PubStatbook.nsf/ f932b66241ecf1b7ca256e92000e23be/54D73763EF9DCA36CA2571B6002428B0/\$FILE/06-043a.pdf (accessed on 2 September 2017).

Hassiotis, Angela, Dina Gazizova, Leah Akinlonu, Paul Bebbington, Howard Meltzer, and Andre Strydom. 2011. Psychiatric morbidity in prisoners with ID: Analysis of prison survey data for England and Wales. The British Journal of Psychiatry 199: 156-57. [CrossRef] [PubMed]

Haysom, Leigh, Devon Indig, Elizabeth Moore, and Cadeyrn Gaskin. 2014. Intellectual disability in young people in custody in New South Wales, Australia-Prevalence and markers. Journal of Intellectual Disability Research 58: 1004-14. [CrossRef] [PubMed]

Hellenbach, Mike, Thanos Karatzias, and Michael Brown. 2017. Intellectual Disabilities among Prisoners: Prevalence and Mental and Physical Health Comorbidities. Journal of Applied Research in Intellectual Disabilities 30: 230-41. [CrossRef] [PubMed]

Holcombe, Sarah. 2015. The contingency of 'rights': Locating a global discourse in Aboriginal Central Australia. Australian Journal of Anthropology 26: 211-32. [CrossRef]

Holland, Shasta, and Peter Persson. 2007. Intellectual Disability in the Victorian Prison System-Characteristics of Prisoners with an Intellectual Disability Released from Prison in 2003-2006. Melbourne: Department of Justice. Available online: https:/ / assets.justice.vic.gov.au/corrections/resources/0423a0c6-958e-4847-904a61032a59a7d9/intellectual_disability_in_the_victorian_prison_system.pdf (accessed on 27 August 2017).

Human Rights and Equal Opportunity Commission. 1997. Bringing Them Home: National Inquiry into the Separation of Aboriginal and Torres Strait Islander Children from Their Families. Report of the National Inquiry into the Separation of Aboriginal and Torres Strait Islander Children from Their Families. Commonwealth of Australia. Available online: https://www.humanrights.gov.au/sites/default/files/ content/pdf/social_justice/bringing_them_home_report.pdf (accessed on 27 August 2017).

Human Rights Law Centre. 2016. Queensland Commits to a Human Rights Act. November 16. Available online: https://www.hrlc.org.au/news/queensland-commits-to-a-human-rights-act (accessed on 2 September 2017).

International Covenant of Civil and Political Rights (ICCPR). 1966. Adopted and Opened for Signature, Ratification and Accession by General Assembly Resolution 2200A (XXI) of 16 December 1966 Entry into Force 23 March 1976, in Accordance with Article 49. Available online: http:/ /www.ohchr.org/EN/ ProfessionalInterest/Pages/CCPR.aspx (accessed on 2 September 2017).

Indig, Devon, Elizabeth McEntyre, Jude Page, and Bronwen Ross. 2010. 2009 Inmate Health Survey: Aboriginal Health Report; Sydney: Justice Health. Available online: http://www.justicehealth.nsw.gov.au/publications/ inmate-health-survey-aboriginal-health-report.pdf (accessed on 27 August 2017).

Kite, Elaine, and Carol Davy. 2015. Using Indigenist and Indigenous methodologies to connect to deeper understandings of Aboriginal and Torres Strait Islander peoples' quality of life. Health Promotion Journal of Australia 26: 191-94. [CrossRef] [PubMed]

Lee, Taryn. 2016. The rights granted to indigenous peoples under international law: An effective means for redressing historical wrongs? International Community Law Review 18: 53-71. [CrossRef]

Maddison, Sarah. 2013. Indigenous identity, 'authenticity' and the structural violence of settler colonialism. Identities-Global Studies 20: 288-303. [CrossRef] 
Maddocks, Tom. 2016. Rosie Ann Fulton: System Has 'Failed' Intellectually Impaired Indigenous Woman. ABC News (Online), 1 July. Available online: http: / www.abc.net.au/news/2016-07-01/carer-says-systemhas-failed-rosie-fulton/7560532 (accessed on 27 August 2017).

Männynsalo, Laura, Hanna Putkonen, Nina Lindberg, and Irma Kotilainen. 2009. Forensic psychiatric perspective on criminality associated with intellectual disability: A nationwide register-based study. Journal of Intellectual Disability Research 53: 279-88. [CrossRef] [PubMed]

Maxwell, Yvonne, Andrew Day, and Sharon Casey. 2013. Understanding the needs of vulnerable prisoners: The role of social and emotional wellbeing. International Journal of Prisoner Health 9: 57-67. [CrossRef] [PubMed]

Mazel, Odette. 2016. Self-determination and the right to health: Australian aboriginal community controlled health services. Human Rights Law Review 16: 323-55. [CrossRef]

McBrien, Judith. 2003. The intellectually disabled offender: Methodological problems in identification. Journal of Applied Research in Intellectual Disabilities 16: 95-105. [CrossRef]

McGaughey, Fiona, Tamara Tulich, and Harry Blagg. 2017. UN decision on Marlon Noble case: Imprisonment of an Aboriginal man with intellectual disability found unfit to stand trial in Western Australia. Alternative Law Journal 42: 67-70. [CrossRef]

McGrath, Pam, and Emma Phillips. 2008. Aboriginal spiritual perspectives: Research findings relevant to end-of-lifecare. Illness Crisis and Loss 16: 153-71. [CrossRef]

Morgan, Neil. 2016. Western Australia's Prison Capacity. Perth: Western Australia. Available online: http:/ / www.parliament.wa.gov.au/WebCMS/WebCMS.nsf/resources / file-tp---oics-wa-prisoncapacity/\$file/OICS\%20WA\%20Prison\%20Capacity.pdf (accessed on 2 September 2017).

National Aboriginal Health Strategy Working Party. 1989. A National Aboriginal Health Strategy. Canberra: National Aboriginal Health Strategy Working Party.

National Aboriginal and Torres Strait Islander Health Council for the Australian Health Ministers' Conference (NATSIHC). 2003. National Strategic Framework for Aboriginal and Torres Strait Islander Health: Context. Canberra: National Aboriginal and Torres Strait Islander Health Council. Available online: https://www.health.gov.au/internet/main/publishing.nsf/Content/ 12B50420F5E0006DCA257BF000199D6C/\$File/nsfatsihcont.pdf (accessed on 27 August 2017).

National Human Rights Consultation Committee (NHRCC). 2009. National Human Rights Consultation Report. September. Available online: http:/ / apo.org.au/system/files/19288/apo-nid19288-69096.pdf (accessed on 2 September 2009).

O'Loughlin, Michael. 2009. A psychoanalytic exploration of collective trauma among Indigenous Australians and a suggestion for intervention. Australasian Psychiatry 17: S33-36. [CrossRef] [PubMed]

Parker, Karen. 1989. Jus Cogens: Compelling the Law of Human Rights. Hastings International and Comparative Law Review 12: 411-64.

Parliament of Australia (Australian Government). 2009. Legal Issues_Australian Human Rights Framework: Budget Review 2010-11: Legal Issues and the Attorney-General's Portfolio. Available online: http:/ / www.aph.gov.au/About_Parliament/Parliamentary_Departments/Parliamentary_Library / pubs/rp/BudgetReview201011/LegalHumanRights\#_edn3 (accessed on 2 September 2009).

Parliament of Australia (Australian Government). 2015. Report: Violence, Abuse and Neglect against People with Disability in Institutional and Residential Settings, Including the Gender and Age Related Dimensions, and the Particular Situation of Aboriginal and Torres Strait Islander People with Disability, and Culturally and Linguistically Diverse People with Disability. 25 November. Available online: http://www.aph.gov.au/Parliamentary_Business/Committees/Senate/Community_ Affairs/Violence_abuse_neglect/Report (accessed on 2 September 2017).

Parliament of Australia (Australian Government). 2016. Report: Indefinite Detention of People with Cognitive and Psychiatric Impairment in Australia. 29 November. Available online: http://www.aph.gov. au/Parliamentary_Business/Committees/Senate/Community_Affairs/IndefiniteDetention45/Report (accessed on 1 September 2017).

Queensland Government. 2014. Daily Life in Prison. November 19. Available online: https://www.qld.gov.au/ law / sentencing-prisons-and-probation/prisons-and-detention-centres/daily-life-in-prison (accessed on 10 July 2017). 
Department of Justice and Attorney-General, Queensland Government. 2016. Annual Report 2015-2016; Brisbane: Queensland Government.

Referendum Council. 2017. Uluru-National Convention. Aboriginal and Torres Strait Islanders Peoples from Across Australia Make Historic Statement (23-26 May 2017). Available online: https://www. referendumcouncil.org.au/event/ first-nations-regional-dialogue-in-uluru (accessed on 6 December 2017).

Rountree, Jennifer, and Addie Smith. 2016. Strength-based well-being indicators for indigenous children and families: A literature review of indigenous communities' identified well-being indicators. American Indian and Alaska Native Mental Health Research 23: 206-20. [CrossRef] [PubMed]

Roy, Meera, and Sivasankaran Balaratnasingam. 2014. Intellectual disability and indigenous Australians: An overview. Asia-Pacific Psychiatry 6: 363-72. [CrossRef] [PubMed]

Schneider, Karen, Juliet Richters, Tony Butler, Lorraine Yap, Alun Richards, Luke Grant, Anthony Smith, and Basil Donovan. 2011. Psychological distress and experience of sexual and physical assault among Australian prisoners. Criminal Behaviour and Mental Health 21: 333-49. [CrossRef] [PubMed]

Shahid, Shaouli, Lizzie Finn, Dawn Bessarab, and Sandra C. Thompson. 2009. Understanding, beliefs and perspectives of Aboriginal people in Western Australia about cancer and its impact on access to cancer services. BMC Health Services Research 9: 132. [CrossRef] [PubMed]

Shepherd, Stephane M., James R. P. Ogloff, Dan Shea, Jeffrey E. Pfeifer, and Yin Paradies. 2017. Aboriginal prisoner and cognitive impairment: The impact of dual disadvantage of Social and Emotional Wellbeing. Journal of Intellectual and Disability Research 61: 385-97. [CrossRef] [PubMed]

Simpson, Jim. 2014. Participants or Just Policed? Guide to the Role of the NDIS-People with Intellectual Disability Who Have Contact with the Criminal Justice System. NSW Council for Intellectual Disability, NSW. Available online: http://www.nswcid.org.au/images/pdf/Participants_or_just_policed_614.pdf (accessed on 27 August 2017).

Simpson, Jim, and Mindy Sotiri. 2004. Criminal Justice and Indigenous People with Cognitive Disabilities: A Scoping Paper. A Discussion Paper Prepared for Aboriginal and Torres Strait Islander Services; Sydney: Beyond Bars Alliance.

Sotiri, Mindy, Patrick McGee, and Eileen Baldry. 2012. No End in Sight: The Imprisonment and Indefinite Detention of Indigenous Australians with Cognitive Impairment. A Report Prepared by the Aboriginal Justice Disability Campaign. September. Available online: https://www.pwd.org.au/documents/pubs / adjc/NoEndinSight.pdf (accessed on 27 August 2017).

Steele, Linda Roslyn. 2016a. Indefinite Detention of People with Cognitive and Psychiatric Impairment. Sydney: Australian Lawyers Alliance. Sydney: Australian Lawyers Alliance.

Steele, Linda. 2016b. Disabling forensic mental healht detention: The carcerality of the disabled body. Punishment and Society 19: 327-47. [CrossRef]

Steering Committee for the Review of Government Service Provision. 2017. Report on Government Services 2017, Volume C, Justice. Canberra: Productivity Commission, vol. C. Available online: http:/ /www.pc.gov. au/research/ongoing/report-on-government-services/2017/justice/rogs-2017-volumec.pdf (accessed on 2 September 2017).

Stewart, John. 2014. Intellectual Impaired Aboriginal Woman Rosie Fulton to Be Freed after 21 Months in Jail with no Conviction. ABC News (Online), June 26. Available online: http:/ / www.abc.net.au/news/2014-06-25/ aboriginal-woman-in-jail-without-conviction-to-be-freed/5550790 (accessed on 27 August 2017).

Stewart, Louise M., C. J. Henderson, Michael S. T. Hobbs, Susy C. Ridout, and Matthew W. Knuiman. 2004. Risk of death in prisoners after release from jail. Australian and New Zealand Journal of Public Health 28: 32-36. [CrossRef] [PubMed]

The SPRINT Project Team. 2013. Primary Health Care Services Better Meeting the Needs of Aboriginal Australians Transitioning from Prison to the Community: SPRINT Final Report. Centre for Primary Health Care and Equity, Faculty of Medicine, University of New South Wales. Available online: http:/ files.aphcri.anu.edu. au/reports/Lloyd.Full.Report.25.pdf (accessed on 27 August 2017).

Tighe, Joe, Kathy McKay, and Myfanwy Maple. 2015. 'I'm going to kill myself if you don't ... ': Contextual aspects of suicide in Australian Aboriginal communities. International Journal of Culture and Mental Health 8: 1-12. [CrossRef]

United Nations General Assembly. 1966. International Covenant on Economic Social and Cultural Rights (ICESCR). New York: United Nations General Assembly. 
United Nations General Assembly. 2007. United Nations Declaration on the Rights of Indigenous Peoples. New York: United Nations General Assembly.

Vanny, Kathryn, Michael Levy, and Susan Hayes. 2008. People with an intellectual disability in the Australian criminal justice system. Psychiatry, Psychology and Law 15: 261-71. [CrossRef]

Victorian Office of Corrections. 1990. Standard Guidelines for Prison Facilities in Australia and New Zealand. Available online: http://assets.justice.vic.gov.au/corrections/resources/86bad68c-de78-44efb06f-20f4c7844e18/standard_guidelines_prison_facilities_1990small.pdf (accessed on 2 September 2017).

Walters, Janice A. 2011. The psychological and social consequences of trauma and race relations on the Australian indigenous people. International Journal of the Humanities 9: 149-64. [CrossRef]

Yap, Mandy, and Eunice Yu. 2016. Operationalising the capability approach: Developing culturally relevant indicators of indigenous wellbeing-An Australian example. Oxford Development Studies 44: 315-31. [CrossRef]

Zillman, Stephanie. 2016. Indefinite Detention of Cognitively and Mentally Impaired People Inquiry Labelled ‘Predictable’. ABC News (Online), April 10. Available online: http:/ /www.abc.net.au/news/2016-04-10/ unfit-to-plead-in-the-nt-inquiry-labelled-predictable/7314268 (accessed on 27 August 2017).

(C) 2018 by the authors. Licensee MDPI, Basel, Switzerland. This article is an open access article distributed under the terms and conditions of the Creative Commons Attribution (CC BY) license (http://creativecommons.org/licenses/by/4.0/). 